\title{
Pussy Riot and the Politics of Profanation : Parody, Performativity, Veridiction
}

\section{Prozorov, Sergei}

2014-11-05

Prozorov , S 2014 , ' Pussy Riot and the Politics of Profanation : Parody, Performativity, Veridiction ' , Political Studies, vol. 62 , no. 4 , pp. 766-783 . https://doi.org/10.1111/1467-9248.12047

http://hdl.handle.net/10138/233446

https://doi.org/10.1111/1467-9248.12047

acceptedVersion

Downloaded from Helda, University of Helsinki institutional repository.

This is an electronic reprint of the original article.

This reprint may differ from the original in pagination and typographic detail.

Please cite the original version. 
This is a post-peer-review, pre-copyedit version of an article published in Political Studies, vol. 62, issue 4. The final authenticated version is available online at: https://doi.org/10.1111/1467-9248.12047.

Sergei Prozorov

\section{Pussy Riot and the Politics of Profanation: Parody, Performativity, Veridiction}

\section{Introduction}

On February 21, 2012 five young women belonging to a 'feminist-punk' group Pussy Riot entered the building of the Cathedral of Christ the Saviour in Moscow and proceeded to the soleas of the cathedral, where they ventured to perform a song entitled 'Mother of God, Drive Putin away!'. The entire performance lasted for 41 seconds, after which the band members were themselves driven out of the building by the guards. The recording of this and a prior similar performance at a lesser-known Moscow church were then used in the music video for the song in question that was posted on YouTube and various social networks, quickly gathering over 600000 views.

The song, which Pussy Riot labelled a 'punk prayer', features strident criticism of the complicity of the Russian Orthodox Church in the authoritarian regime in Russia, focusing on the allegations of corruption in the church establishment, the lavish lifestyles of Patriarch Kirill and other church notables as well as the reported links of the Church with the state security police in the Soviet and post-Soviet eras. This criticism, expressed in the verses set to a punk rock song, is supplemented in the chorus with the injunction to Virgin Mary to 'become a feminist', 'join us in protest' and 'drive Putin away', set to the melody of a traditional Orthodox hymn:

Black robe, golden epaulettes.

All parishioners crawl to bow.

The phantom of liberty is in heaven.

Gay-pride sent to Siberia in chains.

The head of the KGB, their chief saint, Leads protesters to prison under escort. In order not to offend His Holiness

Women must give birth and love.

(Pussy Riot 2012) ${ }^{1}$ 
While the band's video caused an immediate scandal in the Russian blogosphere, it was only on February 26 that a legal case was opened against the members of Pussy Riot, who were accused of 'hooliganism', a charge that in Russia carries a maximum sentence of seven years in prison. The hooliganism in question allegedly consisted in the purposeful offense of the religious sentiments of the employees and other attendees of the Cathedral of Christ the Saviour during the band's 41-second performance as well as numerous others who were offended by watching the music video. On March 4, the day of the Russian presidential elections, two of the band's members, Nadezhda Tolokonnikova and Maria Alekhina, were arrested, and the third one, Ekaterina Samutsevich was detained on March 15. All three were eventually charged with hooliganism and remained in prison custody until the trial that started on July 30 and ended on August 17, 2012 with the conviction of the three band members for hooliganism motivated by religious hatred and the sentencing of all three to two years in prison.

In the course of the trial, which was marked by extreme irregularities that led one of the defense lawyers to proclaim it 'worse than in Stalin's times' (see Elder, 2012), the case of Pussy Riot received increased international attention. The Russian government was criticized for its handling of the case by numerous human rights activists and European politicians while the band received high profile support from fellow musicians, from Madonna to Red Hot Chili Peppers. The case also became the object of intense political and sociocultural debates both inside and outside Russia, broaching such diverse questions as the continuing deterioration of the rule of law in Putin's Russia, the political role of the Orthodox Church, the balance between freedom of speech and respect for religious beliefs, the limits of artistic freedom and the excessively repressive justice system, the conditions of Russian prisons and the lifestyle of Patriarch Kirill, etc. What at first appeared to be merely one more in the series of political provocations of contemporary artists arguably turned into the most important political event in Russia in recent years, even overshadowing the massive protests against election fraud in December 2011-May 2012.

And yet, the meaning of this event remains elusive. Both the detractors of Pussy Riot and many of their supporters appear to share the interpretation of the band's 'punk prayer' as a parody, a prank, a provocation targeting the Russian Orthodox Church and thus belonging to the long and distinguished tradition of the conflict between art and religion. This provocation may then be condemned as offensive to religious believers or defended as a constitutional right. Yet, what is lost in this interpretation is the political force of the performance, which explains both its 'cruel and unusual' persecution by the regime and its appeal to the increasing numbers of the Russian opposition. The presentation of the case in terms of blasphemy and censorship, whereby what is at stake is the freedom of all speech, arguably mutes the significance of the specific kind of speech act practiced by Pussy Riot. 
In this article we reconstruct the political logic underlying this speech act with the help of Giorgio Agamben's theory of profanation. In Agamben's reading profanation refers to the practice of overcoming the separation of objects or phenomena into restricted spheres. While both religious and secular structures of authority operate by isolating and confining various aspects of human existence in 'sacred' spheres that prescribe the possibilities of their practice, profanation reclaims them for free and common use. The strategy of profanation is thus central to Agamben's long-standing confrontation with the Western ontopolitical tradition governed by the logic of sovereignty. While Agamben's critique of this tradition has been widely acclaimed and applied in the studies of contemporary politics, his affirmative or redemptive alternative to it, presented on different occasions as a politics of 'happy life' (1998), 'pure means' (2000), gesturality (2000) and, more recently, profanation (2008) has so far received a rather more mixed response (Franchi, 2004; Edkins, 2007; Mills, 2008, pp. 134-137; Passavant, 2007; De La Durantaye, 2008, 2009, pp. 353-362, Geulen, 2009.) Agamben's affirmative politics has been criticized and even derided as naïve, utopian, ineffective or simply unintelligible (Laclau, 2007; Rasch, 2007; Power 2010). One of the reasons for this is that Agamben usually eschews concrete and detailed examples of the political strategies he devises, affirming them as possibilities of things being radically otherwise rather than as aspects of actual political practices. What appears to be lacking in the discussion of Agamben's politics of profanation are the paradigms of this politics in the sense that Agamben gives to this term (2009b): 'a [singular] case that is isolated from its context only insofar as, by exhibiting its own singularity, it makes intelligible a new ensemble, whose homogeneity it itself constitutes.' (Agamben, 2009b, p. 18) To construct a paradigm of something is to offer an example that would leave its immediate context and constitute a new one, making intelligible the co-belonging of at first glance different cases. In this article we shall rely on the case of Pussy Riot to construct a paradigm of profanatory politics in order both to concretize its logic and to reassess its efficacy.

We shall begin by addressing the singularity of the Pussy Riot trial in the context of the resurgent authoritarianism in contemporary Russia. While the prosecution and the official media campaign against Pussy Riot sought to depoliticize the case by framing it in terms of a blasphemous mockery of religious rituals, we shall argue that Pussy Riot's performance could not possibly be interpreted as a parody that seeks to weaken the force of a practice by relocating it into a comic context. Instead, the logic of Pussy Riot's punk prayer is best grasped in terms of profanation, which seeks to reclaim this force by returning it to free use. While, as we shall show, the logic of parody defines the mainstream political discourse in Putin's Russia, Pussy Riot's punk prayer is exceptional precisely in being not parodic but rather a serious speech act. While the classical speech act theory of J.L. Austin emphasizes the conventional and institutional conditions for the success of a speech act, Agamben's reconstruction of the notion of the performative in the works from The Time that Remains onwards introduces a different understanding of performativity as free 'veridictive' practice similar to Foucault's notion of parrhesia. While Agamben's 'sacramental' performative 
derives its force from and serves to sustain canonical forms of ritual, the illocutionary force of the speech act that Agamben terms performativum fidei consists in liberating speech and praxis from these canonical forms. We shall conclude with a discussion of the effects of this profane performativity for political subjectivation and the wider social transformation.

\section{The Nature of the Offense: Pussy Riot and the Council of Laodicea}

The overwhelmingly aggressive character of the prosecution of Pussy Riot appears extreme even by contemporary Russian standards. What makes this case a landmark event in the reprehensible history of the suppression of political opposition in Putin's Russia is that it was arguably the first time that an act of self-expression on the part of ordinary citizens was punished by actual prison terms. While we previously observed trials and sentencings of 'anti-system' oppositional activists (e.g. the numerous members of Eduard Limonov's banned National Bolshevik Party) and the use of the judicial system against political and economic competitors within the elite (e.g. the case of Mikhail Khodorkovsky's Yukos company), the expression of oppositional views by ordinary citizens was previously not a matter of criminal investigation, unless it took place in the context of the unauthorized public protests akin to Marches of Dissenters in 2007-2009 or 'Strategy 31' marches in 20092011. Prior to the Pussy Riot case one could hardly fear a two-year prison term for oppositional statements, even those stylized in an unconventional and even extreme manner.

Indeed, the protests against Putin and the United Russia party in the aftermath of the allegedly rigged 2011 Duma and 2012 presidential elections featured a myriad of creative anti-Putin slogans, compared to which the call to Virgin Mary to 'drive out' the 'head of the KGB, the chief saint' sounds positively restrained. Moreover, Pussy Riot themselves appeared to have gotten away with their preceding public appearance with a song called 'Putin has pissed himself' that was performed at the Place of Skulls in the Red Square in close proximity to the office of the song's protagonist in December 2011. While state censorship in the mass media has long ensured that no anti-Putin statements, punk or otherwise, ever appeared on state television, Putin-bashing as such has hitherto never been criminalized.

If the anti-Putin character of the performance cannot by itself explain the 'cruel and unusual' character of the prosecution of Pussy Riot, might not an explanation be rather sought in the fact that this performance also explicitly attacked the Orthodox Church and its head Patriarch Kirill (Vladimir Gundyaev).

The Church's praise of rotten dictators, The cross-bearer procession of black limousines, 
A teacher-preacher will meet you at school,

Go to class - bring him money!

Patriarch Gundyaev believes in Putin

Bitch, better believe in God instead.

The belt of the Virgin can't replace mass-meetings.

Mary, Mother of God, is with us in protest! (Ibid.)

Besides the lyrics that accuse the Church of subservience to authoritarian government, corruption, suppression of homosexuality and women's rights, what, in the view of the prosecution and its supporters, made the performance particularly offensive was the fact that the band members had entered the area of the soleas, which is usually off limits to non-clergymen, wearing bright-coloured dresses and balaclavas, which the state prosecutor Alexander Nikiforov deemed 'extremely indecent' (Nikiforov cited in Interfax Editorial 2012). According to the prosecution, the offensive lyrics and the indecent manner of the performance make the three women's behaviour 'vulgar, impudent and cynical', supporting the charge of hooliganism (ibid.).

Throughout the trial, the prosecution forcefully advanced an interpretation of the Pussy Riot performance as a deliberate affront to the religious beliefs of Orthodox Christians, dismissing all references to the political content of the performance as irrelevant: 'The prosecutors do not believe the defendants' allegations that their actions in the church were not driven by hatred and enmity towards Orthodox believers, but were driven by political motives.' (Ibid.) While the members of Pussy Riot and their lawyers insisted on the political significance of their performance, the prosecution sought to reduce it to a blasphemous act, a violation of church ritual that was an offense to practicing Orthodox Christians. In this attempt at depoliticization, the prosecution went so far as to include in its case the references to the rules of liturgical rituals established in 363 AD by the Council of Laodicea (the prohibition for laypersons to sing in the ambon of the cathedral) and in $692 \mathrm{AD}$ by the Quinisext Council (the prohibition of wearing 'comical' or 'satyrical' clothing and performing 'pagan' practices in church). Disregarding the fact that the rules of neither Council are as yet incorporated into the Russian Criminal Code, the prosecution deemed them universally known and abided by in the country, which presumably makes their violation an instance of hooliganism.

Many of the critical commentators gleefully seized on this 'religious' interpretation of the case, eager to demonstrate how ridiculous the literal application of the rules of Laodicea and Quinisext Councils would be not only for laypersons but even the Church officialdom itself. This depoliticizing interpretation of the case has thus also been taken up by the opposite side, whereby the protesters against the sentencing of Pussy Riot begin to view 
Putin's Russia as an aspiring theocracy, in which any mockery of the Orthodox Church carries the threat of a lengthy prison term.

Yet, this is simply not the case. While the Orthodox Church has undeniably become more politically active since the early 1990s and particularly after the election of Patriarch Kirill in 2009, its clout is nowhere near the one required for 'theocratic' ambitions. Moreover, the Church and its leadership have not been spared the critical attention of Russian artists and civic activists even in the Putin period. While the more radical criticism of the church, e.g. the 2003 contemporary art exhibition entitled 'Religion Alert!' or the 2006 'Prohibited Art' exhibition, led to criminal prosecution, the sentences were limited to fines and no arrest or pre-trial detention was ever involved. 'Anti-religious' campaigns and criticism have been a permanent part of Russian cultural life yet have so far aroused only half-hearted indignation and, it must be said, half-hearted interest. Similarly, while Pussy Riot's reference to Patriarch Kirill as a 'bitch' is probably without precedent, the figure of the Patriarch is certainly no stranger to public criticism and even ridicule. The Pussy Riot trial unfolded against the background of media scandals surrounding Patriarch Kirill's lifestyle: the scandals around his lavish penthouse apartment, the price of his Breguet wristwatch and his fleet of luxury cars, etc. It would therefore be overly simplistic to interpret the Pussy Riot case merely as an indicator of the growing political clout of the Orthodox Church.

In order to understand the specificity of this case we must go beyond the one-sided interpretations of the performance as either 'political' (i.e. oppositional) or 'blasphemous' (violating church rituals) but rather take as our point of departure precisely the confluence of the two themes that are evident in the title of the punk prayer: 'Mother of God, Drive Putin away!'. As long as the two themes are isolated, it is difficult to understand what made this case so offensive to the regime that it persisted in the persecution of the band in the face of severe criticism at home and abroad. Whom or what did Pussy Riot really offend? What is it about their punk prayer that simultaneously invited the full-blown assault of the entire repressive apparatus and attracted support from the most diverse of sources? In the following section we shall venture an interpretation of this performance that systematically contrasts it with the logics of blasphemy and parody.

\section{Beyond Parody: Pussy Riot vs The Union of the Militant Godless}

Throughout the Pussy Riot trial both the prosecution and the wider media campaign against the band routinely compared their allegedly blasphemous performance with the antireligious campaigns of the Bolsheviks in the 1920s-1930s, the most extreme and infamous of which was the destruction of churches, including the original Cathedral of Christ the Saviour in 1931 (see Groys, 2008, pp. 101-122). Prosecutor Nikiforov explicitly referred to the band's actions in terms of 'abuse of God' (bogohulstvo), routinely comparing the band 
to the infamous Union of the Militant Godless, an anti-religious movement of the early Soviet period (see Stites, 1989, pp. 101-122):

With regard to the social danger of this crime, it is notable that also from the canonical standpoint of Islam such actions are unacceptable and call for public apology. Any temple carries holiness, a solemn atmosphere that those present in it must maintain. The bacchanalia of this sort throws a challenge to this. This testifies to the moral decline in the society. The keykeeper of the Cathedral has remarked on the similarity of the women's action to the Union of the Godless in the 1920s, parodying processions and collective prayers that subsequently almost led to the destruction of the Russian Orthodox Church. (Nikiforov cited in Kostychenko, 2012)

However understandable it might be as a rhetorical device, the analogy drawn between Pussy Riot's prayer and Bolshevik anti-religious campaigns is entirely implausible. The iconoclastic drive of the art and politics of the 1920s sought to weaken the political and social influence of the Church through public education, propaganda and the counterforce of the new civil religion (Stites, 1989, pp. 109-114). In contrast, Pussy Riot's performance does nothing to undermine religion in general, or Orthodox Christianity in particular, but solely criticizes its implication in contemporary this-worldly politics. There is certainly a difference between an anti-Putin prayer to Virgin Mary that calls on her to become a feminist and a poster of 'Virgin Mary with a bulging belly longing for a Soviet abortion' (ibid., p. 107) or other favourite means of anti-religious propaganda in the early-Soviet period: the exhumation of entombed saints, the violent ridicule of such 'miracles' as 'weeping icons', the burning of the effigies of God, and parodies of church liturgies set to indecent lyrics. This difference may be elaborated by considering the history of the notion of parody, used in the speech of prosecutor Nikiforov.

In his genealogy of parody Giorgio Agamben departs from the conventional understanding of this concept as a strategy that seeks to suspend or deactivate the force of a practice by transferring it to a new domain, usually a less solemn or serious one. Agamben elucidates a more originary sense of the concept, developed in the sphere of musical technique. While in Greek music melody originally corresponded to the rhythm of speech, with the Homeric poems this link is broken, introducing a rupture between music and language, 'the separation of song from speech' (Agamben, 2007, p. 40), whereby speech takes place in the space beside (para) the melody. From this perspective, the very appearance of prose is conditioned by parody, which liberates speech from its union with music. It is this originary sense of parody as the rupture of the natural bond between song and speech that conditions the possibility of parody in the more familiar and limited sense as the transfer of speech to 'improper' contexts.

The performance of Pussy Riot is certainly parodic in this wider and more originary sense of the rupture of the bond between music and speech: their punk prayer offers a perfect 
paradigm of the dissolution of anything like a 'natural bond' between melos and logos, whereby the words of the Orthodox Christian prayer may be relocated to the domain of punk rock or, conversely, loud and abrasive music may become the setting for a prayer. Yet, this general sense of parody is a characteristic of language as such and not a purposeful strategy of the speaker: 'parody is the theory - and practice - of that in language and in being which is beside itself or, the being-beside-itself of every being and every discourse.' (ibid., p. 49) The fact that a logos may be set to a melos that is incongruous with it, and the other way round, only testifies to the absence of any ontological relation of congruity, of a natural bond between them.

Yet, if we consider the Pussy Riot prayer in terms of the more recent and specific sense of parody, things become a lot more complicated. It is far from certain that in this case we may speak of a transfer of discursive content of prayer to a comical context. While the parodies of the Union of the Militant Godless that set pornographic lyrics to liturgical music sought, successfully or otherwise, to make us laugh at what formerly filled us with awe, the prayer to Virgin Mary to drive Putin away clearly serves a rather different function that, moreover, would be seriously jeopardized by the ridicule of the addressee of the petition. Similarly, the lyrics describing the repressive and corrupt character of the Russian state and the complicity of the Church in this repression and corruption may hardly be termed comical or humorous, even in the more acerbic or satirical sense.

The same applies a fortiori to the final statements of the three Pussy Riot members during the trial, which are completely devoid of ridicule or spite but rather repeatedly refer to anger and pain that motivated their performance at the Cathedral of Christ the Saviour.

We are distressed that the great and luminous Christian philosophy is being used so shabbily. We are very angry that something beautiful is being spoiled. It still makes us angry and we find it very painful to watch. (Tolokonnikova, 2012)

Our motivation is more eloquently expressed in the words of the Gospel 'For everyone who asks receives, and he who seeks finds, and to him who knocks it will be opened.' I, and all of us, sincerely believe that it will be opened for us. But, alas, so far the bars are closed on us. (Alyokhina, 2012)

Both the song and the statements are characterized by a decidedly non-ironic rage that contrasts quite sharply with the prevailing attitude to politics among Russian artists, intellectuals and the civil society more generally. This attitude, which in the late-Soviet period received the name 'styob' (literally, 'jibe'), consists in the ironic distancing from all structures of authority and the subjection of the official discourse to a desublimating parody that deprives it of both sense and force. In this manner, styob carries a certain liberating effect for its subject despite leaving the parodied phenomenon strictly intact. By making the maxims of the Soviet ideology meaningless, the practitioners of styob also sought to render 
them powerless with regard to their hold on one's existence. Rather than confront the system frontally and inviting a repressive response, the practitioners of the ethos that may be termed 'para-Soviet' sought to twist loose from the hold of the increasingly sterile ideological maxims and cultivate alternative forms of life at the minimal distance from the official discourse (see Yurchak, 2006, pp. 127-130; Groys, 2003, p. 212; Prozorov, 2009, pp. 107-112).

While styob certainly contributed to the degradation of the Soviet order by desublimating its ideological maxims, its emancipatory effects should not be overestimated. Indeed, the very appeal of the para-Soviet ethos is conditioned by the impossibility or extreme danger of assuming an explicitly anti-Soviet position. It was only because the Soviet system was deemed to be here to stay that it made sense to cultivate livable spaces in its interstices, furnishing them through alternative cultural practices that deactivated the official discourse through ironic parody of its maxims. The eventual success of this deactivation obscured the fact that it was made possible by the prior occupation of the position of extreme disempowerment, lacking any means to confront power directly and reject its ideology explicitly. Conversely, the relative decline of styob under late Gorbachev and Yeltsin testified to the weakening of ideological hegemony and the newly gained possibility to challenge the state frontally on the terrain of ideology and not beside it in the practice of parodic displacement.

The consolidation of the Putin regime from 2004 onwards witnessed a return of the parodic ethos, yet the character of this regime led to an important transformation in its logic. While the Soviet system was characterized by a rigid and monolithic ideological edifice, which underwent almost no transformation since the death of Stalin, the Putin period has been marked by the abandonment of any ideological identification in favour of a thinly disguised nihilism, which has no qualms about borrowing elements from the most disparate ideological orientations, combining them in a logically inconsistent manner and discarding them after use without any regret (see Prozorov, 2009, pp. 69-74, 203-209). While the Soviet regime in its last decades could be accused of no longer believing in its own maxims and concealing this disbelief under the veneer of ideological rigidity, the Putin regime has arguably dispensed with ideology even as a matter of appearance and hence does not even pretend to believe in itself (Mikhailova, 2013, pp. 76-78; cf. Zizek, 1989, pp. 28-30). To laugh at such a system is always already to laugh with it.

The spread of irony, sarcasm and travesty during the Putin period is thus different from the Soviet era in that it carries little or no emancipatory potential. When deployed by the regime itself, it serves to soften the impact of authoritarian rule by suggesting that it is all somehow not serious, an ironic citation from the 'black books' of the 20th century with an obligatory wink at the end. At least until the post-election protests of 2011-2012, the societal response to the regime tended to take the same parodic form, ranging from the refined ironies of critical intellectuals to the shrill and abrasive laughter of such protest-art 
groups as Voina (War), of which Pussy Riot's Nadezhda Tolokonnikova is a former member. In this manner, styob has arguably become the true ideology of postcommunist Russia, whose function is to make laughable everything, including the ruling regime but also every instance of resistance and dissent, which find each other acceptable only insofar as neither of them is ultimately 'for real' (cf. Cassiday and Johnson 2013). The catchword of the regime might be borrowed from Health Ledger's Joker in the Dark Knight: 'why so serious?'

It is precisely this question that lies at the heart of the prosecution of Pussy Riot, whose performances sharply reverse this tendency towards universal laughability. To the extent that we may still speak of parody here, it is a singularly paradoxical case of 'serious parody' (Agamben, 2007, p. 40), which Agamben discusses with reference to modernist Italian literature. The point of such parody is not to relocate something from a serious to a comical context but rather to bring to speech something that in its own 'proper' context has become unspeakable or unnarratable: 'the very object of narration is, in this sense, 'parodic', that is, 'out of place', and the writer can only repeat and mimic the intimate parody of this object.' (ibid., p. 41). In the following section we shall elaborate this notion of serious parody with the help of Agamben's concept of profanation.

How not to Pray in Vain: The Logic of Profanation

The admittedly paradoxical idea of serious parody permits us to identify the difference of the Pussy Riot performance from the parodic blasphemy that the band members were accused and convicted of. In serious parody the displacement of an object or practice to a new context does not seek to transform the serious into the comical but rather to make the serious speakable as serious, i.e. opening it up to a new use after it has become unusable or inoperative in its proper or canonical context. In this emphasis on the return to use, serious parody resonates with the problematic of profanation, which Agamben defined as the overcoming of the separation of an object into a separate, 'sacred' sphere that opens it to free use in a myriad of non-canonical ways (2007, pp. 73-74). In this sense, profanation is constitutively opposed to religion, which 'removes things, places, animals or people from common use and transfers them to a separate sphere' (ibid., p. 74).

Yet, profanation should also be distinguished from secularization, which 'leaves intact the forces it deals with by simply moving them from one place to another' (ibid., p. 77). Both operations may be viewed as forms of parody in the wider sense, yet whereas secularization relocates the sacred object from one domain to another while retaining the principle of its separation, profanation dislocates the line that separates the object from the possibility of free use. 'Both are political operations: the first guarantees the exercise of power by carrying it back to a sacred model; the second deactivates the apparatuses of power and 
return to common use the spaces that power had seized.' (Ibid.) While it seeks to abolish all separate 'sacred spheres', profanation does not negate the content of what is separated within them, hence it cannot be equated with an a priori 'anti-religious' attitude. 'Religio is not what unites men and gods but what ensures they remain distinct. It is not disbelief and indifference towards the divine that stand in opposition to religion, but negligence, that is, a behaviour that is free and 'distracted' before things and their use, before forms of separation and their meaning.' (Ibid., p. 75)

It is important to emphasize that this negligence concerns not the profaned object itself but rather the conditions defining its use, the exclusions and restrictions that endow this object with a specific, privileged or canonical function (ibid., p. 76). From this perspective, Pussy Riot's performance, with its many improprieties regarding its precise location in the cathedral, the attire of the performers, the manner of singing, the content of the lyrics, etc., may be understood as the profanation of the practice of prayer, the overcoming of its separation from the possibility of free use in the sacred sphere of church ritual. If Pussy Riot are indeed 'guilty' of anything, it is precisely this negligence of the various forms of the separation of prayer in the canon that make it impossible to pray to punk rock music, to pray for the removal of the president, to pray in a balaclava or in 'indecent' bright clothes, etc. The overcoming of these forms of separation is parodic in the sense of the rupture of the 'natural bond' between the practice and its mode of application, yet, insofar as this rupture does not relocate the practice of prayer to a comic context akin to the anti-religious performances of the Union of the Militant Godless, this parody is evidently a 'serious' one.

Another way of grasping this seriousness is to focus on the notion of use, central to the concept of profanation. A practice, be it prayer, dance or sexual intercourse, is not profaned in order to be stopped, suspended or removed from use, as was evidently the case with the comic parody of prayer in the Soviet anti-religious propaganda of the 1920s, but, on the contrary, in order to open it to free use that is not reducible to its canonical function. In contrast to early-Soviet parodies, which maintained precisely the ceremonial and canonical aspects of prayer while weakening or demolishing its force through ridicule, the performance of Pussy Riot neglects ceremony and ritual without in any way neglecting the force of prayer. To profane the prayer to Virgin Mary by focusing it on the figure of the president or setting it to punk rock music is not to ridicule it but to make it usable beyond the properly religious sphere, within which it has been separated and contained. In other words, profanatory parody does not seek to deactivate the force of a practice by making it less serious but, on the contrary, to wrest this force away, amplify it and thereby ensure that it is not in vain.

We may now clearly appreciate the difference of the practice of profanation from the comic parody of prayer that takes the form of blasphemy, in which the name of God is precisely 'uttered in vain'. We have already seen that the punk prayer does not fall under the conventional definition of blasphemy as of 'pronouncing of injury or falsity on God' 
(Agamben 2009a, p. 41): there is no injury done to Virgin Mary in asking her to get rid of Putin or become a feminist. Yet, the performance of Pussy Riot is also clearly distinct from the wider, and, again, more originary notion of blasphemy reconstituted by Agamben in his Sacrament of Language. In this text Agamben approaches the notion of blasphemy as a deactivated or inoperative form of an oath:

Blasphemy is an oath, in which the name of a god is extracted from the assertorial or promissory content and is uttered in itself, in vain, independently of semantic content. The name, which in the oath expresses and guarantees the connection between words and things and which defines the truthfulness and force of the logos, in blasphemy expresses the breakdown of this connection and the vanity of human language. (Ibid., pp. 40-41)

To approach the syntagm 'Mother of God, drive Putin away!' in terms of blasphemy is thus simply incorrect both formally and substantively. In the formal sense, this syntagm does not extract the divine name from semantic content, whereby it is uttered alone, by itself and thus in vain, but, on the contrary, links it with a clearly defined object of petition. Similarly, in the more substantial sense, the entire purpose of the performance is to stop the name of the Mother of God being uttered in vain in canonical prayers 'for rotten dictators' and the veneration of dubious relics ('the Virgin's belt') and to mobilize it in the struggle against the allegedly corrupt state and church.

[In] our performance we dared, without the Patriarch's blessing, to combine the visual images of Orthodox culture and protest culture, suggesting that Orthodox culture belongs not only to the Russian Orthodox Church, the Patriarch and Putin, that it might also take the side of civic rebellion and protest in Russia. (Samuts evich, 2012)

Thus, the charges of blasphemy and the offense of religious beliefs are entirely inappropriate in this case: insofar as the prayer in question is meant seriously, i.e. if Pussy Riot really want Virgin Mary to drive Putin away, it cannot possibly be intended for the purposes of ridicule, insult or blasphemy. Yet, it is precisely this seriousness that is properly offensive to the regime. While both the political and the clerical elites could probably live with the parodic blasphemy of religious rituals, which would be a priori ineffective and 'in vain', content with producing a comical version of the parodied practice, what remains intolerable is the profanatory use of prayer, which overcomes its separation from any political use other than the ceaseless glorification of the sovereign, be it heavenly or earthly (Agamben, 2011, pp. 167-194). What the regime prosecutes is not an act of styob, travesty or ridicule, a comical parody of religion and/or ideology, but the profanatory use of prayer as, in terms of Austin's speech act theory, a felicitous speech act. In the following section we shall address Pussy Riot's performance in the context of both classical speech act theory and its reinterpretation in the light of Agamben's theory of profanation. 
The Profane Performative: Returning Blasphemy to Sender

A prayer is a performative speech act in the Austinian sense of an enunciation that is primarily characterized not by 'locutionary' propositional content but by the 'illocutionary' force of an action performed by means of the enunciation itself. A performative act does not (merely) describe a state of affairs but actually produces it: 'I promise' only refers to the reality that it itself constitutes. Similarly, a prayer performs the act of praying, mobilizing and transforming its discursive content into an actual petition. The speech act 'Mother of God, drive Putin away!' is thus a performative utterance that, unlike constative statements (e.g. 'Patriarch Kirill's watch costs USD 30000)', cannot be adjudicated as to its truth or falsity. Instead, it must be approached in terms of what Austin refers to as 'felicity' or 'infelicity', i.e. success or failure in undertaking the action in question (Austin, 1976, p. 42). This performative efficacy must in turn be distinguished from the success or failure of the action itself that are covered by the 'perlocutionary' dimension of the speech act, i.e. whether a promise is kept, the threat succeeds in deterring, or whether Mother of God does indeed drive Putin away (ibid., p. 91). The illocutionary force of the action, which may be felicitous or not, does not pertain to its effects or consequences but solely to the undertaking of the action itself, which may either be completed successfully or end up void due to a number of possible 'infelicities'.

Austin's examples of performative utterances primarily refer to conventional acts, e.g. marriage, naming, opening a ceremony, etc. The emphasis on conventionality also characterizes his well-known threefold scheme for the felicity conditions of a speech act:

(A. 1) There must exist an accepted conventional procedure of uttering certain words in certain circumstances.

(A. 2) The persons uttering those words must be the accepted ones.

(B. 1) The procedure must be executed by all participants both correctly and

(B. 2) completely.

(C. 1) Where the procedure is designed for persons having certain thoughts or intentions, the persons in question must indeed have those thoughts.

(C. 2) Where a subsequent conduct is part of the procedure, the persons must conduct themselves accordingly. (Ibid., p. 15)

It is easy to see that the first two groups of conditions ( $A, B)$ may be said to be external to the speaker, pertaining to the existence of the conventional procedure of producing the acts in question and its correct execution. Even the second, internal or 'psychological' group of conditions remains tied to this external procedure since it pertains to having thoughts or intentions presupposed by it or conducting oneself in accordance with its prescriptions. From this perspective, it is hardly surprising that any analysis of Pussy Riot's punk prayer as 
a performative act, an 'exercitive' or a 'behabitive' in Austin's tentative classification (see ibid., pp. 155-161) would proclaim this act to be 'infelicitous' in a number of ways.

It might be viewed as a misfire which both misinvokes the procedure of prayer by introducing political content into it and misexecutes it with flaws pertaining to the band's inappropriate attire and manner of praying and hitches due to the band's being kicked out from the church after less than a minute. It is this aspect of misfire that the prosecution sought to prove with their references to the early mediaeval church councils prescribing the proper procedure for prayer or other behavior in the church. Alternatively, the performance may be viewed as an abuse of procedure due to the alleged insincerity of the performers, who, according to the prosecution, did not have the proper thoughts or intentions when praying to Virgin Mary but only sought to ridicule and humiliate other, genuine believers (cf. ibid., pp. 16-18). Insofar as the felicity of a speech act depends on external conditions pertaining to the existence and correct execution of the conventional procedure, any act that is not in conformity with it remains void and is accessible only as an a priori ineffective parodic displacement. The practice of profanation, which consists precisely in the attempt to liberate a speech act from the conventional procedure, within which its illocutionary force is captured, would only be able to produce ineffective misfires or blasphemous abuse.

However, Austin's approach has been subjected to a critical reinterpretation that emphasizes the contingency of the conventional procedure. We need only recall Pierre Bourdieu's forceful restoration of the dimension of social or symbolic power as a condition of possibility of the external felicity conditions themselves (1992, pp. 73-74) or Jacques Derrida's demonstration of the impossibility of separating 'serious' from 'non-serious' or 'parasitic' invocations of performative formulae due to the general iterability of all linguistic marks (1988, pp. 15-18). The former reminds us that the force of performative formulae does not inhere in these formulae themselves but rather has the weight of the entire social order behind it, which delegates to some and not others the power of doing things with words. The latter demonstrates that this power must nonetheless presuppose, structurally and necessarily, the possibility of its own ruin in the proliferation of 'non-serious' (i.e. not properly socially authorized) use of performative formulae, whose condition of possibility is exactly the same as that of the most serious ones. If the procedure that authorizes and contains the performative force of an utterance is itself a product of power and if there always remains a possibility of wresting this force away through iteration, then the conventional or ritualized form of the performative that Agamben (2005, p. 134) terms performativum sacramenti is always necessarily contaminated by another kind of performative, which is the 'other' of all convention or ritual.

Agamben's distinction between the two types of performatives is of particular interest to us, since it is articulated in the context of Pauline messianism and pertains precisely to the problematics of prayer and blasphemy, sacrament and profanation that we focus on in this article. In his Time that Remains Agamben reconstructs the gospel (euaggelion) or the 'word 
of faith' in Pauline epistles in terms of the logic of the performative: '[The] experience of the word of faith does not entail the experience of a denotative character of the word, its referring to things, but enacts its meaning through its utterance.' (Agamben, 2005, p. 131) Yet, in contrast to the 'sacramental performative', which is both enabled by and itself reinforces the operation of the existing social order (nomos), the messianic 'word of faith' rather brings the nomos to fulfilment by deactivating it and rendering it inoperative. Agamben terms this singular form of the performative performativum fidei and compares it to Foucault's reconstruction of the Greek notion of parrhesia or 'veridiction' (Foucault, 2010, 2011). While constative statements are independent of the enunciating subject and their truth is evaluated by logical and objective criteria, in veridiction the subject constitutes itself through its truth-telling, 'linking itself performatively to the truth of its own affirmation' (Agamben, 2009a, p. 57).

[What] we today call a performative in a strict sense are the relics in language of this constitutive experience of speech - veridiction - that exhausts itself with its utterance, since the speaking subject neither pre-exists it nor is subsequently linked to it but coincides integrally with the act of speech. When Paul, in Romans 10: 6-10 defines the word of faith (to rema tes pistes) not by means of the correspondence between word and reality but by means of the closeness of 'lips' and 'heart', it is the performative experience of veridiction that he has in mind. (Ibid., p. 58)

How are these two performatives related to each other? Both the 'sacramental' and the 'faithful' performative are nothing other than 'a revelation of language itself, an experience of a pure event of the word that exceeds every signification' (Agamben, 2005, p. 134). Yet, while the 'sacramental' performative attempts to encapsulate this excess by 'articulating it in precepts and semantic contents, [using it] as a means to ground contract and obligation' (ibid., pp. 134-135), performativum fidei maintains this excess beyond any determinate signification, 'open[ing] up the space for gratuitousness and use as an expression of the subject's freedom' (Agamben, 2005, p. 135). Insofar as the latter speech act is necessarily fleeting, since it exhausts itself in its utterance, its durable effects can only be produced in the orderly form of the sacramental performative. The historical institution of the Church may then be grasped as a necessarily fragile and problematic attempt to articulate the two performatives:

The attempt to reconcile faith as the performative experience of a veridiction with belief in a series of dogmas of an assertive type is the task and at the same time the central contradiction of the Church, which obliges it, against the clear evangelical command, to technicalize oaths and curses in specific juridical institutions. (Agamben, 2009a, p. 66. See more generally Agamben, 2012)

For both law and religion to function, both performative operations are necessary: 'if the performativum fidei is completely covered by the performativum sacramenti, then the law 
itself stiffens and atrophies and relations between men lose all sense of grace and vitality.' (Agamben, 2005, p. 135) It is precisely this situation of atrophy that Maria Alekhina, one of the convicted members of Pussy Riot, presented in her closing statement at the trial as the key motivation for the group's punk prayer:

[The] gospel is no longer understood as revelation, which it was initially, but as a kind of solid block which can be torn up to quotations and tucked anywhere, into any document, used for any purpose. [In accusing Pussy Riot of blasphemy], the Russian Orthodox Church didn't even bother to examine the context in which the word 'blasphemy' is used [in the New Testament], that in this case it is applied to Jesus Christ himself. (Alekhina, 2012)

The degradation and corruption of the institution of the church that the band's punk prayer describes is only the most extreme case of the domination of performativum fidei by performativum sacramenti, the reduction of the Church to a nomological ordering power, deprived of all sense of grace. 'With the eclipse of the messianic experience of the culmination of the law and of time comes an unprecedented hypertrophy of law - one that under the guise of legislating everything, betrays its legitimacy through legalistic excess.' (Agamben 2012, p. 40). Insofar as the two performatives are separated, the nomos, both secular and clerical, ends up devoid of veridiction, the subjective experience of truth, and becomes literally vain, i.e. blasphemous in the originary sense.

When the ethical - and not simply cognitive - connection that unites words, things and human actions is broken, this in fact promotes a spectacular and unprecedented proliferation of vain words on the one hand, and on the other, of legislative apparatuses that seek obstinately to legislate on every aspect of that life on which they seem to longer to have any hold. (Agamben, 2009a, p. 71)

The accusation of blasphemy that was the central aspect of the prosecution's case must therefore be finally returned to sender, or, rather, to the protagonists of the punk prayer. Insofar as Pussy Riot target the atrophy of both state and church, both law and religion, as a result of the separation of performative veridiction into a separate 'sacramental' sphere, it is ultimately they who accuse both the secular and clerical authorities of true blasphemy that takes the form of the combination of vain discourse and repressive regulation (cf. Zizek, 2012).

And yet, Pussy Riot's performance is not exhausted by a critique of this reduction of the institution of the church to sacramental conventions that deprive religion of its originary messianic vocation. Precisely insofar as it takes the form of a prayer and takes place at the site intended for prayer, it is an attempt to go beyond lamenting the demise of the 'word of faith' towards its actual restitution. Since the existing structures of secular and clerical authority have dispensed with veridiction in favour of the sacramental reproduction of the 
existing order, such a restitution can only take the form of profanation, which would wrest away the illocutionary force of prayer from its confinement in the 'conventional procedure'.

This is why, against first appearances and the conventionalist reading of Austin, Pussy Riot's prayer is a felicitous speech act, not in the sense of abiding by the conventional procedure but in the sense of rendering it inoperative and thereby opening the speech act in question to free non-canonical use. We ought to recall that the felicity of the performative does not pertain to its perlocutionary effect, which could only be assessed in the case of Virgin Mary's response to the petition, but solely its illocutionary force. In our case this force consists precisely in practicing prayer outside and even against any conventional procedure that regulates its possible use.

The logics of parody and profanation are thus clearly opposed. While parody, including blasphemy as its extreme form, violates the conditions of felicity to achieve a comic effect, for which it is ready to sacrifice the illocutionary force of the speech act, profanation seeks to salvage and amplify precisely this force that is deemed at the risk of atrophy due to its sedimentation and ritualization. The use of prayer in the free practice of veridiction might thus be understood as the fulfilment of parody in the Hegelian sense of Aufhebung that simultaneously conserves and displaces it (cf. Agamben, 2007, pp. 50-51). A practice can only be parodied as long as it is not successfully profaned, as long as it remains separated and proscribed from free use - only then is it possible to relocate it to the space 'para', beside the sphere of its canonical use. When this separation is overcome in profanation, there is no more need for parody, since there is no longer a privileged place, alongside which a more comic, crude or otherwise different version of this practice might be presented. While parody makes it possible to live beside the dominant order, while submitting its ideology to blasphemous ridicule, profanation targets its very dominance as itself a form of blasphemy, which is to be overcome through the free practice of veridiction.

\section{Conclusion}

Yet, what does this veridictive performative achieve in the political domain? Does not our analysis of the Pussy Riot case ultimately bring us back to the familiar criticism of Agamben's politics as naïve, vacuous and ineffective, opting for radical utopian gestures over the daily demands of pragmatic politics or, for that matter, the discipline of revolutionary militancy (see e.g. Laclau, 2007, p. 22; Rasch, 2007, pp. 107-108; Geulen, 2009, pp. 27-28; Kaufman, 2008, pp. 49-51). Of course, the efficacy of any political practice depends on the context in which it unfolds. Just as parodic reiteration of ideological maxims was effective in the lateSoviet conditions and entirely impotent in Putin's Russia, so the efficacy of the politics of performative profanation is likely to vary across contexts, depending on the extent and intensity of 'sacramental' separations within a society that withdraw practices or objects from free common use. It is only in a society that has completely dispensed with the very 
principle of separation that the politics of profanation would have nothing to do. While the magnitude of the state campaign against Pussy Riot offers sufficient evidence that their politics is not perceived as harmless utopianism by the regime, its actual mode of efficacy may be elaborated by revisiting the relation of 'profane performativity' to the ancient Greek practice of 'free-spokenness' (parrhesia), central to Foucault's late writings.

While Foucault analysed a plurality of modes of parrhesia and recognized their political ambivalence (2012, pp. 57-69), all these modes share a common feature of dispensing with the rhetorical style of the Sophists in favour of a 'pure', unconcealed and straight discourse, devoid of any irony: 'in parrhesia, as if it were a veritable anti-irony, the person who tells the truth throws the truth in the face of his interlocutor, a truth which is so violent, so abrupt, and said in such a peremptory and definitive way that the person facing him can only fall silent, or choke with fury.' (Foucault, 2011, p. 54, see also ibid., pp. 327-336, Foucault, 2012, p. 234) Parrhesia excludes the very possibility of ironic distance and is wholly contained in 'the manifestation, in complete nakedness, of the truth of the world and of life' (Foucault, 2012, p. 183). This feature is taken to the extreme in the Cynic parrhesia that Foucault addressed at the end of his 1983-1984 lecture course. For the Cynics, 'another life' attained in the practice of parrhesia, a bare, destitute and brute mode of existence and speech, is not merely a mode of self-fashioning or care of the self but rather a form of subjectivation that conditions the possibility of a wider transformation: '[the Cynic] transposes anew the idea of an other life into the theme of a life whose otherness must lead to the change of the world.' (ibid., p. 287). By virtue of their negligence of all conventional procedures regulating truth-telling, the Cynics introduced a dimension of otherness at the heart of the idea of truth, making every act of veridictive subjectivation a part of the transformation of the wider world: 'Through this dissonant irruption of the 'true life' in the midst of the chorus of lies and pretences, of accepted injustice and concealed iniquities, the Cynic makes 'an other world' loom up on the horizon, the advent of which would presuppose the transformation of the present world.' (Gros, 2011, p. 354) The effect of the politics of profanation is then nothing other than the profanation of politics, i.e. its reclaiming for free common use for the purpose of social transformation.

Throughout the Putin era most of what passed for 'critical' or 'oppositional' discourse in Russia was expressed in ironic terms, whose cultivated distance from the object of their criticism ensured the impossibility of the profanation of the political realm. By ridiculing Putinite authoritarianism, this discourse only augmented its own separation from politics, its own non-political, non-serious and hence non-subjective status. In contrast to the practice of veridiction, in which the subject is constituted by putting itself at stake in its speech acts, ironic detachment from political reality logically entails the suspension of political subjectivation, which explains the extreme weakness of oppositional activity during the first 12 years of Putin's rule - a tendency only reversed in the 2011-2012 post-election protests. While the regime is accustomed to laughingly dealing with being laughed at, it is at a loss when faced with serious speech acts that posit and enact the possibility of another life, 
another subject and another politics, if only by performing another kind of prayer. This explains the overwhelmingly repressive response of the regime to what to many observers inside and outside Russia first appeared to be merely a playful prank. If Pussy Riot poses a serious challenge to Putin's rule, this is because their practices of profanation bring seriousness back into the politics that hitherto thrived on chuckles, winks and putting inverted commas around everything, whereby all things appeared only as 'so-called'. The effect of Pussy Riot's practices of profanation consists in the restitution of the performative efficacy of speech as a condition for political subjectivation and social transformation. In a system that seeks to render all speech vain and impotent, their profane prayer testifies to the possibility of things being otherwise. It is therefore only fitting that we shall leave the last word to one of them.

I'm not scared of you. I'm not afraid of lies and sham, poorly decorated lies in the verdict of this so-called court, because you only can deprive me of socalled freedom. This is the only type of freedom existing in Russian Federation. My inner freedom no one can take from me. It lives and will live on through the word, thanks to openness, when thousands of people will read it and hear. This freedom persists with each concerned person, who hears us in this country. With everybody who found pieces of this trial in themselves, as once did Franz Kafka and Guy Debord. I believe that it is honesty and openness, thirst for truth which will make us a little freer. We will see this. (Alekhina, 2012) 
NOTES

${ }^{1}$ Throughout this article we use the official English translation of Pussy Riot lyrics, available at http://freepussyriot.org/content/lyrics-songs-pussy-riot. Our only modification of the translation pertains to the title of the song 'Bogoroditsa, Putina progoni!', which we translate as 'Mother of God, Drive Putin away' and not 'put Putin away' as the website translation does. We do this to avoid the misunderstanding that might be caused by the familiar meanings of the idiom 'to put someone away' in the English language, i.e. to kill someone, to put someone in prison or to put someone to a mental institution. None of these meanings are suggested by the Russian 'progoni', which refers to sending someone away in disgrace, banishing or exiling someone.

\section{BIBLIOGRAPHY}

Agamben, G. (1998) Homo Sacer: Sovereign Power and Bare Life. Stanford: Stanford University Press.

Agamben, G. (2000) Means without End: Notes on Politics. Minneapolis: University of Minnesota Press.

Agamben, G. (2005) The Time that Remains: A Commentary on the Letter to the Romans. Stanford: Stanford University Press.

Agamben, G. (2007) Profanations. New York: Zone Books. 
Agamben, G. (2009a) The Sacrament of Language: An Archaeology of the Oath. Stanford: Stanford University Press.

Agamben, G. (2009b) The Signature of All Things: On Method. New York: Zone Books.

Agamben, G. (2011) The Kingdom and the Glory: For a Theological Genealogy of Economy and Government. Stanford: Stanford University Press.

Agamben, G. (2012) The Church and the Kingdom. New York: Seagull Books.

Alyokhina, M. (2012), Closing Statement: http://freepussyriot.org/content/mashaalyokhinas-closing-statement (accessed 30 August 2012).

Austin, J.L. (1976) How to Do Things with Words. Oxford: Oxford University Press.

Bourdieu, P. (1992) Language and Symbolic Power. London: Polity.

Cassiday, J. and Johnson, E. (2013) 'A Personality Cult for the Postmodern Age: Reading Vladimir Putin's Public Persona', in H. Goscilo (ed.) Putin as Celebrity and Cultural Icon (London: Routledge).

De La Durantaye, L. (2008), 'Homo profanus: Giorgio Agamben's Profane Philosophy', Boundary 2, 35 (3): 27-62.

De La Durantaye, L. (2009), Giorgio Agamben: A Critical Introduction. Stanford: Stanford University Press.

Derrida, J. (1988), Limited, Inc. Chicago: Northwestern University Press.

Edkins, J. (2007) 'Whatever Politics', in M. Calarco and S. DeCaroli (eds) On Agamben: Sovereignty and Life. Stanford: Stanford University Press.

Elder, M. (2012), 'Pussy Riot Trial Worse than Soviet Era', The Guardian, August 3: http://www.guardian.co.uk/world/2012/aug/03/pussy-riot-trial-russia (accessed 4 August 2012) 
Foucault, M. (2010) The Government of Self and Others: Lectures at the College de France 1982-1983. Basingstoke: Palgrave.

Foucault, M. (2011) The Courage of Truth: Lectures at the College de France 1983-1984. Basingstoke: Palgrave.

Franchi, S. (2004) 'Passive Politics', Contretemps, 5, 30-41.

Geulen, E. (2009) 'The Function of Ambivalence in Agamben's Reontologization of Politics' in C. Strathausen and W. Connolly (eds), A Leftist Ontology: Beyond Leftism and Identity Politics. Minneapolis: University of Minnesota Press.

Gros, F. (2011) 'Course Context' in M. Foucault, The Courage of Truth: Lectures at the College de France 1983-1984. Basingstoke: Palgrave.

Groys, B. (2003) Iskusstvo Utopii (Moskva: Khudozhestvenny Zhurnal).

Groys, B. (2008) Art Power. Cambridge: The MIT Press.

Interfax Editorial (2012), August 7: http://www.interfax-religion.com/?act=news\&div=9660 (accessed 17 August 2012)

Kaufman, E. (2008) 'The Saturday of Messianic Time: Agamben and Badiou on Apostle Paul', South Atlantic Quarterly, 107 (1), 37-54.

Kostychenko, E. (2012) 'Sedmoi Den' Slushaniy po Delu Pussy Riot', Novaya Gazeta, 7 August: http://www.novayagazeta.ru/news/58806.html (accessed 10 August 2012)

Laclau, E. (2007) 'Bare Life or Social Indeterminacy' in M. Calarco and S. DeCaroli (eds) On Agamben: Sovereignty and Life. Stanford: Stanford University Press.

Mikhailova, T. (2013) 'Putin as the Father of the Nation: His Family and Other Animals', in H. Goscilo (ed.) Putin as Celebrity and Cultural Icon (London: Routledge). 
Passavant, P. A. (2007) 'The Contradictory State of Giorgio Agamben', Political Theory, 35 (2), 147-174.

Power, N. (2010), 'Potentiality or Capacity: Agamben's Missing Subjects'. Theory and Event, 13 (1): http://muse.jhu.edu/journals/theory_and_event/v013/13.1.power.html (accessed 1 July 2011)

Prozorov, S. (2009), The Ethics of Postcommunism: History and Social Praxis in Russia (Basingstoke: Palgrave).

Pussy Riot (2012) 'Mother of God, Drive Putin Away': http://freepussyriot.org/content/lyrics-songs-pussy-riot (accessed 2 August 2012) Rasch, W. (2007) 'From Sovereign Ban to Banning Sovereignty' in M. Calarco and S. DeCaroli (eds), Giorgio Agamben: Sovereignty and Life. Stanford: Stanford University Press.

Samutsevich, E. (2012) Closing Statement: http://freepussyriot.org/content/katjasamutsevich-closing-statement-criminal-case-against-feminist-punk-group-pussy-riot (accessed 17 August 2012)

Stites, R. (1989) Revolutionary Dreams: Utopian Vision and Experimental Life in the Russian Revolution. Oxford: Oxford University Press.

Tolokonnikova, N. (2012) Closing Statement: http://freepussyriot.org/content/nadiatolokonnikovas-closing-statement (accessed 17 August 2012)

Yurchak, A. (2006) Everything Was Forever until It Was No More: The Last Soviet Generation. Berkeley: Berkeley University Press.

Zizek, S. (1989) The Sublime Object of Ideology (London: Verso).

Zizek, S. (2012), 'The True Blasphemy', The Symptom:

http://www.lacan.com/thesymptom/?page_id=2364 (accessed 21 August 2012) 
